\title{
Epidemiology of hepatitis E virus in children
}

Cite this article as: Mandal A, Singh A. Epidemiology of hepatitis E virus in children. Turk Pediatri Ars 2017; 52: 180-1.

Dear editor,

We read with much interest the article that Bayham et al. (1) published in the recent issue of your journal. First, we would like to commend the authors for their endeavor, but at the same time, would like to make the following comments for clarification, which would benefit the general readers of the journal:

The authors included "children aged between 0 and 18 years" for this seroprevalence and the youngest participant was aged 2 months. The hepatitis $\mathrm{E}$ virus (HEV), which is predominantly spread by the 'feco-oral' route, is very unlikely to infect infants, especially those under 6 months of age who are breastfeeding, unless the authors also wanted to study cases of vertical transmission of the disease (2).

It is not clear why the authors chose to compare the studied population with those having HEV IgG positivity in an attempt to find risk factors for HEV infection, instead of comparing HEV IgG positive vs. HEV IgG negative patients.

It is also not clear as to why the authors chose to study 'history of surgery' as a possible risk factor because it is not a usual mode of transmission of HEV.

The authors did not provide the definition/criteria used for the studied characteristics such as county village, town center, city water.
The authors compared the prevalence of HEV IgG positivity with other available studies. However, while doing so, it is very important to consider the assay used for measuring HEV IgG. It has been observed in comparative evaluation that different assays for HEV IgG perform compared very poorly in their performance characteristics with seroprevalence rates in the same cohort varying by several-folds when different assays were used (3).

\section{References}

1. Bayhan Gİ, Demiören K, Güdücüoğlu H. Epidemiology of hepatitis $\mathrm{E}$ virus in children in the province of Van, Turkey. Turk Pediatri Ars 2016; 51: 148-51.

2. Singh S, Mohanty A, Joshi YK, Deka D, Mohanty S, Panda SK. Mother-to-child transmission of hepatitis E virus infection. Indian J Pediatr 2003; 70: 37-9.

3. Aggarwal R. Diagnosis of hepatitis E. Nat Rev Gastroenterol Hepatol 2013; 10: 24-33.

\section{Anirban Mandal ${ }^{1}$, Amitabh Singh ${ }^{2}$}

${ }^{1}$ Department of Pediatrics, Sitaram Bhartia Institute of Science and Research, New Delhi, India

${ }^{2}$ Department of Pediatrics, Chacha Nehru Bal Chikitsalaya, New Delhi, India 


\section{Re: Epidemiology of hepatitis E virus in children}

Thank you very much for your close interest in our study. Our responses to the questions you asked are listed below:

As you stated, the main route of transmission in HEV infection is the fecal-oral route, and hepatitis E seropositivity in infants substantially reflects the antibodies transferred from the mother. The reason that we also included children aged below six months was the fact that breastmilk might not be the only source of nutrition in this age group and nutritional supplements including mainly water might be given besides breastmilk. Therefore, we also included patients below the age of six months in our study.

We had already compared the HEV IgG-positive subjects with the HEV IgG negative subjects in our study. However, we only showed the HEV IgG positive subjects in the table.

It is known that hepatitis E may be transmitted by blood transfusion $(1,2)$. History of surgery was interrogated because patients with a history of surgery might have received blood transfusions.
In our country, the definitions of locations are made according to the population. In Turkey, locations where 150 people inhabit are called villages. Locations with a population above 2000 and below 20,000 are called towns, and locations with a population above 20,000 are called cities. What we mean by "city water" is water running in the water supply network in cities that is safe for drinking.

\section{Gülsüm İclal Bayhan", Kaan Demirören², Hüseyin Güdüicüoğlu ${ }^{3}$}

${ }^{1}$ Department of Pediatrics, Pediatric Infectious Diseases Clinic, Yüzüncü Yll University Faculty of Medicine, Van, Turkey

${ }^{2}$ Pediatric Gastroenterology Clinic, Dörtçelik Children's Hospital, Bursa, Turkey

${ }^{3}$ Department of Microbiology, Yüzüncü Yll University Faculty of Medicine, Van, Turkey

\section{References}

1. Matsubayashi K, Nagaoka Y, Sakata H, et al. Transfusiontransmitted hepatitis $\mathrm{E}$ caused by apparently indigenous hepatitis E virus strain in Hokkaido, Japan. Transfusion 2004; 44: 934-40. [CrossRef]

2. Boxall E, Herborn A, Kochethu G, et al. Transfusiontransmitted hepatitis $\mathrm{E}$ in a 'nonhyperendemic' country. Transfusion Med 2006; 16: 79-83. [CrossRef]

Address for Correspondence: Gülsüm İclal Bayhan E-mail: gibayhan@gmail.com

DOI: 10.5152/TurkPediatriArs.2016.130601 